\title{
Effect of lengthening alkyl spacer on hydroformylation performance of tethered-phosphine modified $\mathrm{Rh} / \mathrm{SiO}_{2}$ catalyst
}

\author{
Jia Liu a,c, Li Yan a,b,\#, Miao Jiang a,c, Cunyao Li a,c, Yunjie Ding a,b,* \\ a Dalian National Laboratory for Clean Energy, Dalian Institute of Chemical Physics, Chinese Academy of Sciences, Dalian 116023, Liaoning, China \\ b State Key Laboratory of Catalysis, Dalian Institute of Chemical Physics, Chinese Academy of Sciences, Dalian 116023, Liaoning, China \\ c University of Chinese Academy of Sciences, Beijing 100049, China
}

\section{A R T I C L E I N F O}

Article history:

Received 24 August 2015

Accepted 10 November 2015

Published 5 February 2016

Keywords:

Tethered phosphine

Chain length

Rhodium

Silica

Hydroformylation

\section{A B S T R A C T}

$\mathrm{Rh} / \mathrm{SiO}_{2}$ catalysts with tethered-phosphines with different alkyl spacer lengths have been prepared, tested and characterized. Lengthening the alkyl spacer of the tethered-phosphine improved the flexibility of tethered-phospine, promoted the formation of active species and enhanced the activity of hydroformylation over other tethered-phosphine modified $\mathrm{Rh} / \mathrm{SiO}_{2}$ catalysts.

(C) 2016, Dalian Institute of Chemical Physics, Chinese Academy of Sciences. Published by Elsevier B.V. All rights reserved.

\section{Introduction}

Aldehydes, the products of olefin hydroformylation, are important intermediates in the production of many organic compounds and have significant value in industry. Homogeneous catalysts are the most commonly used in industrial hydroformylation processes because of their high activity, high selectivity and mild reaction conditions. However, they require complex and costly separation steps to be removed from the reactants and products. In contrast, heterogeneous catalysts can easily be separated from the reaction mixture but their application in hydroformylation industrial processes has been restricted by their low activity and low selectivity [1,2]. For decades, researchers have explored new catalytic systems combining the advantages of heterogeneous and homogeneous catalysts, and the heterogenization of homogeneous catalysts is one of these hotspots.

A common strategy for heterogenizing homogeneous catalysts is immobilization or heterogenization of a transition-metal complex on a solid support. Immobilization of transition-metal complex on solid supports has achieved some success by chemically bonding the complex to a support, but these catalysts tend to leach the active species into the reaction mixture and thus deactivates the catalyst [3-5].

We have reported a new tethered-phosphine modified $\mathrm{Rh} / \mathrm{SiO}_{2}$ catalyst with excellent stability for use in the hydroformylation of ethylene [6]. Both tethered-phosphines and the supported active metal nanoparticles were anchored to $\mathrm{SiO}_{2}$, which contributed to the remarkable stability of the catalyst. However, as the phosphines and metal nanoparticles were both

\footnotetext{
* Corresponding author. Tel/Fax: +86-411-84379143; E-mail: dyj@dicp.ac.cn

\# Corresponding author. Tel/Fax: +86-411-84379055; E-mail: yanli@dicp.ac.cn

This work was financially supported by the National Natural Science Foundation of China $(21273227,20903090)$.

DOI: 10.1016/S1872-2067(15)61019-1 | http://www.sciencedirect.com/science/journal/18722067 | Chin. J. Catal., Vol. 37, No. 2, February 2016
} 
fixed, their mobility was restricted, and some of the tethered-phosphines could not reach, and coordinate to, the $\mathrm{Rh}$ nanoparticles efficiently to form the active species, which resulted in relative low catalytic activity in the olefin hydroformylation.

Ligand flexibility and projection into solution are related to the chain length of the ligand, and Zhou et al. [7,8] have reported a series of $\mathrm{S}-\mathrm{C}_{n}-\mathrm{PPh}_{2}-\mathrm{Rh}$ catalysts in which $\mathrm{Rh}$ complexes were immobilized onto SBA-15 by anchored phosphines with different chain lengths. The catalysts showed excellent activities in 1-octene hydroformylation but the $\mathrm{P} / \mathrm{Rh}$ molar ratios were variable and significant $\mathrm{Rh}$ leaching occurred. In our catalytic system, lengthening the alkyl spacer of the tethered-phosphine may enhance the coordination between the tethered-phosphine and the metal nanoparticles, increase the number of active species, and thus improve the activity of the tethered-phosphine modified $\mathrm{Rh} / \mathrm{SiO}_{2}$ catalyst. In this work, a phosphine with a longer alkyl spacer was prepared, and then used in the production of a $\mathrm{Rh} / \mathrm{SiO}_{2}$ catalyst. The influence of the alkyl spacer length of the phosphine on its catalytic activity was studied and characterized by $\mathrm{N}_{2}$ adsorption-desorption, in situ Fourier Transform infrared (in situ FT-IR) spectroscopy, and solid-state ${ }^{31} \mathrm{P}$ nuclear magnetic resonance (31P NMR).

\section{Experimental}

\subsection{Catalysts preparation}

$\mathrm{Rh} / \mathrm{SiO}_{2}$ was prepared by impregnating silica gel $(\geq 99 \%$, amorphous silica, Ordos Chemical Co. Ltd., 20-40 mesh, BET surface $=256.3 \mathrm{~m}^{2} / \mathrm{g}$, total pore volume $=0.95 \mathrm{ml} / \mathrm{g}$, average pore radius $=7.4 \mathrm{~nm}$ ) with $\mathrm{RhCl}_{3} \cdot x \mathrm{H}_{2} \mathrm{O}(37.22 \mathrm{wt} \% \mathrm{Rh}$, Johnson Matthey) in ethanol. After drying in air, the $\mathrm{RhCl}_{3} /$ silica was calcined at $573 \mathrm{~K}$ for $4 \mathrm{~h}$ and then reduced in a $\mathrm{H}_{2}$ flow at $573 \mathrm{~K}$ for $4 \mathrm{~h}$ at atmospheric pressure. Then, it was washed to remove $\mathrm{Cl}^{-}$, dried at $393 \mathrm{~K}$, reduced again and restored in an Ar atmosphere. The Rh loading was $1.2 \mathrm{wt} \%$.

2-(Diphenylphosphino)ethyltriethoxysilane

$\left[\mathrm{Ph}_{2} \mathrm{P}\left(\mathrm{CH}_{2}\right)_{2} \mathrm{Si}\left(\mathrm{OC}_{2} \mathrm{H}_{5}\right)_{3}\right.$, referred as DPPETS $]$ was bought from J\&K Scientific and 3-(Diphenylphosphino)propyl-triethoxysilane $\left[\mathrm{Ph}_{2} \mathrm{P}\left(\mathrm{CH}_{2}\right)_{3} \mathrm{Si}\left(\mathrm{OC}_{2} \mathrm{H}_{5}\right)_{3}\right.$, referred as DPPPTS] was prepared according to a literature method [9]. The tethered-phosphine modified DPPETS-Rh/SiO 2 and DPPPTS-Rh/SiO 2 catalysts were prepared as described in the Ref. [6]. $\mathrm{Rh} / \mathrm{SiO}_{2}$ was added to a solution of DPPETS (or DPPPTS) in toluene and the P/Rh molar ratio was 2.24. The mixture was stirred for $16 \mathrm{~h}$ at room temperature and then for a further $6 \mathrm{~h}$ at reflux. After cooling to room temperature, the toluene was removed under vacuum. All manipulations referring to the use of phosphine were carried out under an Ar atmosphere.

\subsection{Catalytic activity}

The catalytic performance of ethylene hydroformylation over the tethered-phosphine modified $\mathrm{Rh} / \mathrm{SiO}_{2}$ catalysts was tested in a stainless steel continuous flow fixed-bed reactor with inner diameter of $6 \mathrm{~mm}$. The reaction was conducted un- der the following conditions: $0.3 \mathrm{~g}$ of sample, the pressure of reactant $\left(\mathrm{C}_{2} \mathrm{H}_{4}: \mathrm{CO}: \mathrm{H}_{2}=1: 1: 1\right) 1.0 \mathrm{MPa}$, temperature $393 \mathrm{~K}$, and the GHSV of reactant $2000 \mathrm{~h}^{-1}$. No gaseous products could be detected in the tail gas, and the main product in the aqueous sample was propanal. The effluent was passed through a condenser filled with $70 \mathrm{ml}$ of de-ionized water giving an aqueous solution of propanal, which remained completely dissolved for the duration of the experiment. The activity of the catalyst was measured by the turn-over-frequency (TOF) of propanal on the basis of the $\mathrm{Rh}$ loaded, counting all $\mathrm{Rh}$ atoms as active sites.

\subsection{Catalyst characterization}

$\mathrm{N}_{2}$ adsorption-desorption isotherms of the samples were measured using a Quantachrome Autosorb-1 instrument to obtain the textural properties of catalysts. The in situ FT-IR spectra were recorded on a Thermo Scientific iS50 instrument equipped with a high temperature high pressure cell (Specas). A sample of $15 \mathrm{mg}$ was pressed into a self-supporting disc. The adsorption of $\mathrm{CO}$ and $\mathrm{H}_{2}$ was performed on the disc at $323 \mathrm{~K}$ and atmospheric pressure. The ${ }^{31} \mathrm{P}$ NMR spectra were acquired using a VARIAN infinity plus spectrometer. The Rh concentrations of catalysts were analyzed by inductively coupled plasma optical emission spectrometry (ICP-OES).

\section{Results and discussion}

\subsection{Catalytic studies}

Fig. 1 shows the catalytic performance of the modified $\mathrm{Rh} / \mathrm{SiO}_{2}$ catalysts with different alkyl spacer lengths of the tethered-phosphine. The TOFs of the catalysts in Fig. 1 increased with the time on stream, implying a gradual formation of the active species on the catalysts during the ethylene hydroformylation reaction. The TOF reached a steady state after $400 \mathrm{~h}$. The TOF of DPPETS-Rh/SiO 2 was only $20.9 \mathrm{~h}^{-1}$, while that of DPPPTS- $\mathrm{Rh} / \mathrm{SiO}_{2}$ reached $40.7 \mathrm{~h}^{-1}$. Both catalysts were higher than $\mathrm{Rh} / \mathrm{SiO}_{2}\left(\mathrm{TOF}=0.8 \mathrm{~h}^{-1}\right.$ ) [10]. Thus, lengthening the alkyl spacer of the tethered-phosphine increased the activity of the tethered-phosphine modified $\mathrm{Rh} / \mathrm{SiO}_{2}$. The ICP-OES results

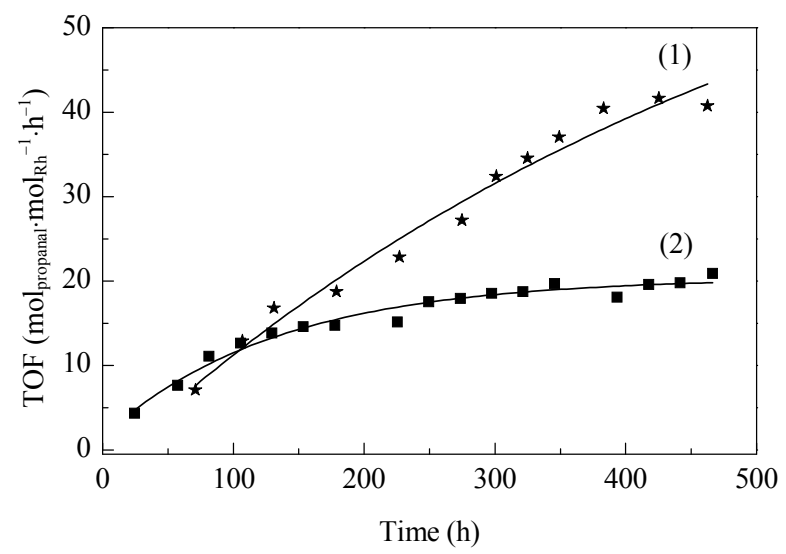

Fig. 1. Catalytic performance of hydroformylation of ethylene over DPPPTS-Rh/SiO 2 (1) and DPPETS-Rh/SiO 2 (2) catalysts at $P=1 \mathrm{MPa}, T$ $=393 \mathrm{~K}$ and $\mathrm{GHSV}=2000 \mathrm{~h}^{-1}$. 


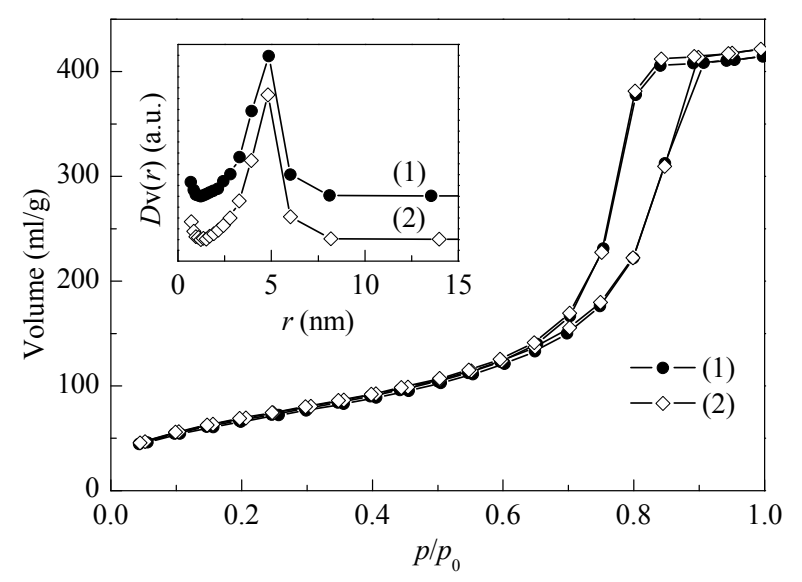

Fig. 2. $\mathrm{N}_{2}$ adsorption-desorption isotherms and corresponding pore size distributions (insert) for DPPPTS-Rh/SiO ${ }_{2}(1)$ and DPPETS-Rh/SiO (2) catalysts.

showed that very little Rh leaching had occurred, even after long reaction times: $11040 \mathrm{ppm}$ Rh for the fresh DPPETS-Rh/ $\mathrm{SiO}_{2}$, compared with $10060 \mathrm{ppm}$ Rh for the used one, and $10450 \mathrm{ppm}$ Rh for the fresh DPPPTS-Rh/SiO 2 and $10580 \mathrm{ppm}$ Rh for the used catalyst.

The preparation of pure phosphines with longer alkyl spacers was hindered by the formation of cyclic compounds that did not contain the $\mathrm{PPh}_{2}$ group. This paper therefore focuses on the available chain lengths, and other, longer chains will be presented later.

\section{2. $N_{2}$ adsorption-desorption results}

$\mathrm{N}_{2}$ adsorption-desorption isotherms and corresponding pore size distributions of DPPETS- $\mathrm{Rh} / \mathrm{SiO}_{2}$ and DPPPTS-Rh/ $\mathrm{SiO}_{2}$ are shown in Fig. 2, and the detailed values are listed in Table 1 . It can be seen that the catalysts had only small differences in pore structure, pore size distribution, BET surface $\left(S_{\mathrm{BET}}\right)$, total pore volume $\left(V_{\mathrm{p}}\right)$ and average pore radius $\left(R_{\mathrm{p}}\right)$. In other words, lengthening the alkyl spacers of the tethered-phosphine did not change the textural properties of the catalysts and mass transfer during the reaction. Hence, the difference in activity of catalysts was not the result of their textural properties.

\subsection{In situ FT-IR}

In situ FT-IR is a powerful technique in identifying the active adsorbed species on heterogeneous catalysts. Fig. 3 shows the in situ FT-IR spectra of $\mathrm{H}_{2}$ and $\mathrm{CO}$ co-adsorbed on the surfaces of the DPPPTS-Rh/SiO 2 and DPPETS-Rh/SiO 2 catalysts. Five bands at 2071, 2039, 2005, 1991 and $1948 \mathrm{~cm}^{-1}$ appeared in

Table 1

Textural properties of the catalysts.

\begin{tabular}{|c|c|c|c|}
\hline Catalyst & $S_{\text {BET }}\left(\mathrm{m}^{2} / \mathrm{g}\right)$ & $V_{\mathrm{p}}(\mathrm{ml} / \mathrm{g})$ & $R_{\mathrm{p}}(\mathrm{nm})$ \\
\hline DPPPTS-Rh/SiO ${ }_{2}$ & 244.4 & 0.6 & 5.3 \\
\hline DPPETS-Rh/SiO ${ }_{2}$ & 256.5 & 0.7 & 5.1 \\
\hline
\end{tabular}

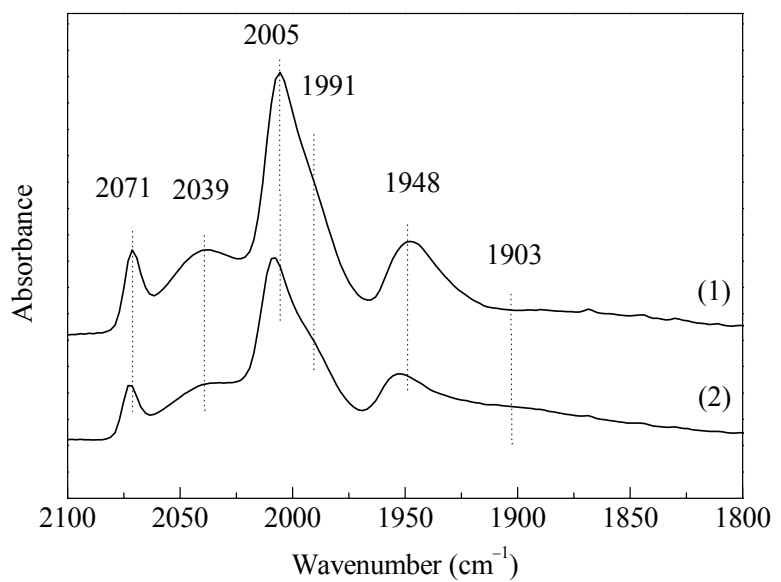

Fig. 3. In situ FT-IR spectra of $\mathrm{CO}$ and $\mathrm{H}_{2}$ co-adsorbed on DPPPTS-Rh/ $\mathrm{SiO}_{2}$ (1) and DPPETS-Rh/SiO 2 (2) catalysts at atmospheric pressure and $323 \mathrm{~K}$ for $0.5 \mathrm{~h}$.

the DPPPTS-Rh/SiO 2 . The bands at 2071 and $1991 \mathrm{~cm}^{-1}$ have been assigned to $e e-\mathrm{HRh}(\mathrm{CO})_{2}(\mathrm{DPPPTS})_{2} / \mathrm{SiO}_{2}$ (i.e., tethered $e e-\mathrm{HRh}(\mathrm{CO})_{2}$ (DPPPTS $)_{2}$ on $\mathrm{SiO}_{2}$ ), while the bands at 2005 and $1948 \mathrm{~cm}^{-1}$ have been assigned to $e a-\mathrm{HRh}(\mathrm{CO})_{2}(\mathrm{DPPPTS})_{2} / \mathrm{SiO}_{2}$ [10-12].The band at $2039 \mathrm{~cm}^{-1}$ has been assigned to linear adsorbed CO, as Rh-CO [13-14]. This band has been significantly red-shifted compared with the heterogeneous $\mathrm{Rh} / \mathrm{SiO}_{2}$ catalyst [15-17], because of the weaker $\mathrm{C}-0$ bond resulting from $\pi^{*}$ back-donation from the Rh to the $\mathrm{CO}$ in the presence of the tethered-phosphine. There were five analogous bands in the spectrum of DPPETS-Rh/SiO 2 , which were similarly assigned to $e e-\mathrm{HRh}(\mathrm{CO})_{2}(\mathrm{DPPETS})_{2} / \mathrm{SiO}_{2}$, ea-HRh(CO) 2 (DPPTES)2/ $\mathrm{SiO}_{2}$ and the linear $\mathrm{CO}$ adsorbed on the $\mathrm{Rh}$ nanoparticles, respectively. Compared with the bands of DPPPTS-Rh/SiO 2 , the spectrum of DPPETS- $\mathrm{Rh} / \mathrm{SiO}_{2}$ was slightly blue-shifted, a result of the different tether length on the $\mathrm{Rh} / \mathrm{SiO}_{2}$ catalysts.

Because $\mathrm{HRh}(\mathrm{CO})_{2}(\mathrm{DPPPTS})_{2} / \mathrm{SiO}_{2}$ and $\mathrm{HRh}(\mathrm{CO})_{2}(\mathrm{DPPETS})_{2} /$ $\mathrm{SiO}_{2}$ are the analogous active species for the homogeneous Wilkinson-type hydroformylation [18], they were assumed to be the active species that catalyzed the olefin hydroformylation on the tethered-phosphine modified $\mathrm{Rh} / \mathrm{SiO}_{2}$ catalysts. Furthermore, linear $\mathrm{CO}$ has been shown to promote hydroformylation in heterogeneous catalysts [19]. The FT-IR spectrum of DPPPTS-Rh/SiO 2 was more intense than DPPETS-Rh/SiO 2 Rasband et al. [20] have reported the concentration of adsorbed $\mathrm{CO}$ is proportional to the corresponding FT-IR band intensity. The increased band intensity implies higher concentration of $\mathrm{CO}$ was adsorbed on the catalysts. Therefore, higher concentration of $\mathrm{CO}$ has been adsorbed on the DPPPTS- $\mathrm{Rh} / \mathrm{SiO}_{2}$ catalyst than on the DPPPET-Rh/SiO 2 catalyst, which explains the increased activity of DPPPTS- $\mathrm{Rh} / \mathrm{SiO}_{2}$. In addition, a band at $1903 \mathrm{~cm}^{-1}$ appeared in the DPPETS-Rh/SiO 2 catalyst, but was not seen in the DPPPTS-Rh/SiO 2 spectrum. This band has been assigned to bridging $\mathrm{CO}$ on the Rh nanoparticles [21], suggesting that some $\mathrm{Rh}$ atoms on DPPETS- $\mathrm{Rh} / \mathrm{SiO}_{2}$ were not modified by the tethered-phosphine and remained as $\mathrm{Rh}$ nanoparticles. This would also contribute to relative low catalytic activity of DPPETS- $\mathrm{Rh} / \mathrm{SiO}_{2}$. 


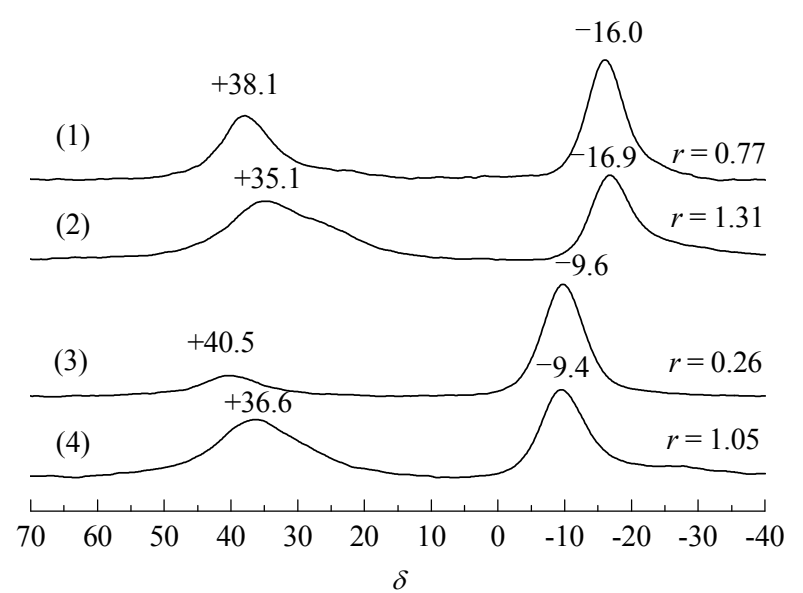

Fig. 4. ${ }^{31} \mathrm{P}$ NMR spectra of the fresh $\mathrm{DPPPTS}-\mathrm{Rh} / \mathrm{SiO}_{2}$ (1), used DPPPTS- $\mathrm{Rh} / \mathrm{SiO}_{2}$ (2), fresh DPPETS- $\mathrm{Rh} / \mathrm{SiO}_{2}$ (3), and used DPPETS- $\mathrm{Rh} / \mathrm{SiO}_{2}$ (4) catalysts.

\section{4. ${ }^{31} P$ NMR results}

Fig. 4 displays the ${ }^{31 P}$ NMR spectra of fresh and used DPPPTS-Rh/SiO 2 and DPPETS-Rh/SiO 2 catalysts. The spectrum of the fresh DPPPTS-Rh/SiO 2 shows bands at -16.0 and +38.1 ppm, assigned to free DPPPTS tethered to the $\mathrm{SiO}_{2}$ carrier, and tethered-DPPPTS coordinated to $\mathrm{Rh}$ nanoparticles, respectively $[6,10,22]$. Two bands at -16.9 and +35.1 ppm can be observed in the spectrum of used DPPPTS-Rh/SiO 2 , which have shifted up-field compared with the fresh one. This shift is because of a change in the chemical environment of the phosphorous in the used sample. Similarly, the fresh and used DPPETS-Rh/SiO catalysts also show two bands assigned to free DPPETS-SiO and coordinated tethered-DPPETS, respectively.

The down-field band $(\alpha)$ and up-field band $(\beta)$ were integrated and the ratios of the areas of band $\alpha$ to band $\beta(r)$ are shown in Fig. 4. For both catalysts, the $r$ value of the used catalyst was higher than that of the fresh one, which means more phosphine was coordinated to the $\mathrm{Rh}$ nanoparticles after the hydroformylation reaction. The gradual formation of the active tethered Rh-phosphine complex as the reaction proceeded confirms the previous results where the TOF increased with time on stream. The $r$ value of the used DPPPTS-Rh/SiO 2 (1.31) was significantly higher than that of the used DPPETS-Rh/SiO (1.05). This observation suggests that the proportion of the tethered-phosphine coordinated to the $\mathrm{Rh}$ nanoparticles in DPPPTS-Rh/SiO 2 was higher than in DPPETS-Rh/SiO 2 , corroborating the assumption that tethered-phosphines with longer alkyl spacers can more easily coordinate to Rh nanoparticles to form a more active Rh-phosphine complex than those with shorter alkyl spacers.

\section{Conclusions}

This study shows that the catalytic activity of tethered-phosphine modified $\mathrm{Rh} / \mathrm{SiO}_{2}$ catalyst for olefin hydroformylation could be improved by lengthening the alkyl spacer of the tethered-phosphine. In situ FT-IR results confirmed that the active species were a $\mathrm{HRh}(\mathrm{CO})_{2}(\mathrm{DPPPTS})_{2} / \mathrm{SiO}_{2}$ or $\mathrm{HRh}(\mathrm{CO})_{2}$ (DPPETS $)_{2} / \mathrm{SiO}_{2}$ complex. The intensity of the IR bands showed higher concentration of active species were formed on the catalyst modified by the tethered-phosphine with the longer alkyl spacer. ${ }^{31} \mathrm{P}$ NMR results suggest that it is easier for the tethered-phosphine with longer alkyl spacer to coordinate to $\mathrm{Rh}$ nanoparticles and produce the active Rh-phosphine complex. In conclusion, lengthening the alkyl spacer of the tethered-phosphine was beneficial in forming more active species and enhancing the performance of tethered-phosphine modified $\mathrm{Rh} / \mathrm{SiO}_{2}$ catalysts for olefin hydroformylation.

\section{References}

[1] J. Sakauchi, H. Sakagami, N. Takahashi, T. Matsuda, Y. Imizu, Catal. Lett., 2005, 99, 257.

[2] J. Y. Kim, J. H. Park, O. S. Jung, Y. K. Chung, K. H. Park, Catal. Lett,, 2009, 128, 483.

[3] C. W. Jones, M. W. McKittrick, J. V. Nguyen, K. Q. Yu, Top. Catal., 2005, 34, 67.

[4] P. Li, S. Kawi. J. Catal., 2008, 257, 23.

[5] I. Such-Basanez, C. Salinas-Martinez de Lecea, M. C. Roman-

\section{Graphical Abstract}

Chin. J. Catal., 2016, 37: 268-272 doi: 10.1016/S1872-2067(15)61019-1

\section{Effect of lengthening alkyl spacer on hydroformylation performance of tethered-phosphine modified $\mathrm{Rh} / \mathrm{SiO}_{2}$ catalyst}

Jia Liu, Li Yan*, Miao Jiang, Cunyao Li, Yunjie Ding * Dalian Institute of Chemical Physics, Chinese Academy of Sciences; University of Chinese Academy of Sciences

Lengthening the alkyl spacer of the tethered-phosphine was beneficial in forming more active species and enhancing the catalytic performance of a tethered-phosphine modified $\mathrm{Rh} / \mathrm{SiO}_{2}$ catalyst for ethylene hydroformylation.

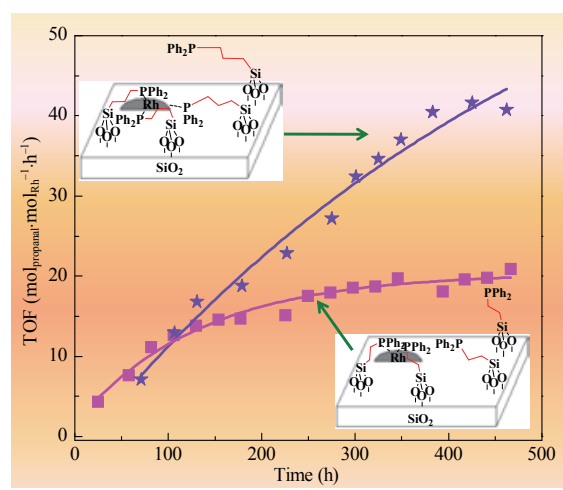


Martinez, Curr. Catal., 2012, 1, 100.

[6] X. M. Li, Y. J. Ding, G. P. Jiao, J. W. Li, R. H. Lin, L. F. Gong, L. Yan, H. J. Zhu, Appl. Catal. A, 2009, 353, 266.

[7] W. Zhou, D. H. He, Chem. Commun., 2008, 5839.

[8] W. Zhou, D. H. He, Green. Chem., 2009, 11, 1146.

[9] M. Capka, Synth. React. Inorg. Metal-Org. Chem., 1977, 7, 347.

[10] J. Liu, L. Yan, Y. J. Ding, M. Jiang, W. D. Dong, X. G. Song, T. Liu, H. J. Zhu, Appl. Catal. A, 2015, 492, 127.

[11] S. Shylesh, D. Hanna, A. Mlinar, X. Q. Kŏng, J. A. Reimer, A. T. Bell, ACS. Catal., 2013, 3, 348.

[12] A. Riisager, R. Fehrmann, S. Flicker, R. van Hal, M. Haumann, P. Wasserscheid, Angew. Chem. Int. Ed., 2005, 44, 815.

[13] S. C. Chuang, R. W. Stevens Jr., R. Khatri. Top. Catal., 2005, 32, 225.
[14] M. Y. Chen, W. Z. Weng, W. Q. Hua, X. D. Yin, H. L. Wan, Chin. J. Catal., 2011, 32, 672.

[15] K. A. Almusaiteer, S. S. Chuang, J. Phys. Chem. B, 2000, 104, 2265.

[16] H. M. Yin, Y. J. Ding, H. Y. Luo, D. P. He, J. M. Xiong, W. M. Chen, Z. D. Pan, L. W. Lin, Chin. J. Catal., 2004, 25, 547.

[17] L. Yan, Y. J. Ding, H. J. Zhu, J. M. Xiong, T. Wang, Z. D. Pan, L. W. Lin, J. Mol. Catal. A, 2005, 234, 1.

[18] D. Evans, J. A. Osborn, G. Wilkinson, J. Chem. Soc. A, 1968, 3133.

[19] S. S. C. Chuang, S. I. Pien, J. Catal., 1992, 135, 618.

[20] P. B. Rasband, W. C. Hecker, J. Catal., 1993, 139, 551.

[21] C. Yang, C. W. Garl, J. Phys. Chem., 1957, 61, 1504.

[22] J. R. Chang, H. M. Lin, S. W. Cheng, C. K. Tseng, D. L. Tzou, S. G. Shyu, J. Mol. Catal. A, 2010, 329, 27.

\title{
膦配体链长对针合膦配体修饰的 $\mathrm{Rh} / \mathrm{SiO}_{2}$ 催化剂上氢甲酰化反应性能的影响
}

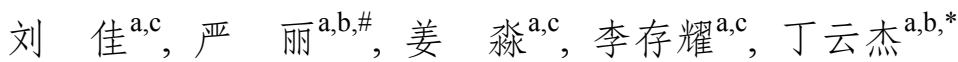 \\ a 中国科学院大连化学物理研究所, 清洁能源国家实验室(筹), 辽宁大连 116023 \\ b 中国科学院大连化学物理研究所, 催化基础国家重点实验室, 辽宁大连 116023 \\ ${ }^{\mathrm{c}}$ 中国科学院大学, 北京100049
}

摘要: 烯烃氢甲酰化反应产物醛是生产多种有机化合物的重要中间体, 具有重要的工业价值. 均相催化剂具有反应条件温 和及催化效率高的优点, 因而成为工业应用的主要催化体系, 但催化剂分离复杂且昂贵. 多相催化剂具有易分离和易回收 的优点, 但在氢甲酰化反应中的活性和选择性较低, 因而大大阻碍了其在工业上的应用. 为了得到兼具两种催化剂优点的 新型催化剂, 人们进行了数十年的研究, 均相催化剂多相化便是其中一个研究热点. 实现该策略最常用的一个方法是将均 相催化剂固载到载体上, 以此来达到催化剂易从反应物及产物中分离, 同时保有高活性高选择性的目的. 通过化学键将金 属配合物的配体键合到载体上已经取得了一定的成功,但依然存在着活性组分流失和催化剂失活的问题.

本课题组开发了一种针合膦配体修饰的 $\mathrm{Rh} / \mathrm{SiO}_{2}$ 新型催化剂, 在乙烯氢甲酰化反应中表现出卓越的稳定性, 反应 $1000 \mathrm{~h}$ 后依然没有出现活性下降和组分流失的现象, 这是因为配体和活性金属同时被固载在载体 $\mathrm{SiO}_{2}$ 上. 但是由于配体和活性金 属都不能自由移动, 很多配体不能与金属原子有效接触，起不到配位效应,因而催化剂活性仍不够高. 因此, 为了提高针合 膦配体修饰的 $\mathrm{Rh} / \mathrm{SiO}_{2}$ 催化剂的活性, 我们合成了具有较长链长的膦DPPPTS, 并与商业购买的链长较短的膦DPPETS做对 比, 研究针合膦配体链长和催化剂活性的关系. 使用 $\mathrm{N}_{2}$ 物理吸附、原位红外光谱(FT-IR)和固体 ${ }^{31} \mathrm{P}$ 核磁共振(NMR)等探讨了 膦配体链长影响催化性能的原因.

固定床上乙烯氢甲酰化反应结果表明, 当膦配体的链长增长一个亚甲基长度后, 反应稳定后催化剂的活性提高了一倍 以上. $\mathrm{N}_{2}$ 物理吸附实验表明, 延长配体的链长对催化剂结构性质的影响不大, 因而也不会改变反应时的传质. 催化剂吸附 合成气 $\left(\mathrm{CO}: \mathrm{H}_{2}=1: 1\right)$ 的原位FT-IR结果表明, 不同链长膦配体修饰的 $\mathrm{Rh} / \mathrm{SiO}_{2}$ 催化剂上均原位生成了类似于用于均相氢甲酰 化反应的Wilkinson型催化剂的活性物种 $\mathrm{HRh}(\mathrm{CO})_{2}(\mathrm{DPPPTS})_{2}\left[\right.$ 或 $\mathrm{HRh}(\mathrm{CO})_{2}(\mathrm{DPPETS})_{2}$ ], 以及吸附在 Rh上的线式CO. 这两 种吸附物种均利于氢甲酰化反应的进行, 其中以前者活性更好. 从原位FT-IR结果同样看出, 针合链长较长的膦配体的催 化剂(DPPPTS- $\mathrm{Rh} / \mathrm{SiO}_{2}$ ) 上原位生成的活性物种量更多, 因而催化活性更高. 固体 ${ }^{31} \mathrm{P} N \mathrm{~N}$ 结果表明, 催化剂上的膦以自由态 的膦(高场峰 $\beta$ )和与 $\mathrm{Rh}$ 配位的膦 (低场峰 $\alpha$ )两种形式存在. $\alpha$ 峰面积和 $\beta$ 峰面积之比 $(r)$ 越高代表与 $\mathrm{Rh}$ 配位的膦配体占总膦量 的比例越高. 发现DPPPTS-Rh/SiO 2 催化剂的 $r$ 值(1.31)高于DPPETS- $R h / \mathrm{SiO}_{2}$ 催化剂(1.05), 即前者与Rh配位生成活性物种的 膦配体的比例更高.

结合原位FT-IR 和固体 ${ }^{31}$ P NMR的结果可知, 链长较长的DPPPTS更容易与Rh配位, 从而生成更多的铑膦配合物活性物 种, 因而催化剂活性更高. 因此, 增长针合膦配体的链长有助于提高其修饰的 $\mathrm{Rh} / \mathrm{SiO}_{2}$ 催化剂的活性.

关键词: 针合膦; 链长; 铑; 硅胶; 氢甲酰化

收稿日期: 2015-08-24. 接受日期: 2015-11-10. 出版日期: 2016-02-05.

*通讯联系人. 电话/传真: (0411)84379143; 电子信箱: dyj@dicp.ac.cn

\#通讯联系人. 电话/传真: (0411)84379055; 电子信箱: yanli@dicp.ac.cn

基金来源：国家自然科学基金(21273227, 20903090).

本文的英文电子版由Elsevier出版社在ScienceDirect上出版(http://www.sciencedirect.com/science/journal/18722067). 